\title{
Structural insights into sGC activation by different activators
}

\author{
Focco van den Akker ${ }^{1 *}$, Faye Martin', Vijay Kumar' ${ }^{1}$ Xiaolei Ma ${ }^{1}$, Johannes-Peter Stasch², Martina Schaefer ${ }^{2}$, \\ Padmamalini Baskaran ${ }^{3}$, Annie Beuve ${ }^{3}$, Pete W van Dunten ${ }^{4}$ \\ From 5th International Conference on cGMP: Generators, Effectors and Therapeutic Implications \\ Halle, Germany. 24-26 June 2011
}

\section{Background}

The soluble guanylyl cyclase (sGC) is a key enzyme involved in the production of the second messenger cGMP. Due its cardiovascular relevance, sGC has been the target of numerous drug discovery efforts leading to the development of many different activators and stimulators with pharmaceutical potential. One of such compounds is the sGC activator Cinaciguat (BAY 58-2667) which is in clinical trials for acute decompensated heart failure.

\section{Results}

We present here our latest structure-function studies related to sGC activation by different sGC activators. The activator complex structures reveal an intriguing mode of heme mimicry by these compounds. The observed activation conformational changes center around the $\alpha \mathrm{F}$ helix that contains the $\mathrm{H} 105$ residue normally held in place by the heme moiety in the absence of the activators.

\section{Conclusion}

The structural insights gained from the complex structures could be used for further optimization and development of sGC activators.

\section{Author details}

'Department of Biochemistry/RT500, Case Western Reserve University, Cleveland, $\mathrm{OH}$ 44106, USA. ${ }^{2}$ Cardiovascular Research, Bayer Schering Pharma AG, Wuppertal D-42096, Germany. ${ }^{3}$ Department of Pharmacology and Physiology, New Jersey Medical School, U. Of Medicine and Dentistry of New Jersey, Newark, NJ 07103, USA. ${ }^{4}$ Stanford Synchrotron Radiation Laboratory, Stanford University, Menlo Park, CA 94025, USA.

\footnotetext{
* Correspondence: focco.vandenakker@case.edu

'Department of Biochemistry/RT500, Case Western Reserve University, Cleveland, OH 44106, USA

Full list of author information is available at the end of the article
}

Published: 1 August 2011

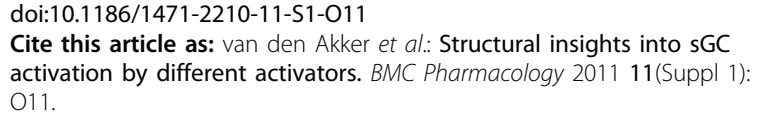

Cite this article as: van den Akker et al:: Structural insights into SGC activation by different activators. BMC Pharmacology 2011 11(Suppl 1): 011.

Submit your next manuscript to BioMed Central and take full advantage of:

- Convenient online submission

- Thorough peer review

- No space constraints or color figure charges

- Immediate publication on acceptance

- Inclusion in PubMed, CAS, Scopus and Google Scholar

- Research which is freely available for redistribution
() Biomed Central

\section{(CiolMed Central}

